\title{
Use of Antibiotics in Dental Implant Surgery: A Decision Based on Evidence from Systematic Review
}

\author{
Uso de Antibióticos en la Cirugía de Implantes Dentales: \\ una Decisión Basada en la Evidencia desde la Revisión Sistemática
}

Claudia Asenjo-Lobos"; Jorge Jofre"; Marcela Cortes ${ }^{*+*+} \&$ Manterola Carlos

ASENJO-LOBOS, C.; JOFRE, J.; CORTES, M. \& MANTEROLA, C. Use of antibiotics in dental implant surgery: a decision based on evidence from systematic review. Int. J. Odontostomat., 9(1):137-147, 2015.

\begin{abstract}
Questions remain whether postoperative infections and implant failure can be reduced with the use of antibiotics. Especially, when its routine use can cause adverse effects and may contribute to the development of antibioticresistant bacteria. Moreover, there is no consensus regarding appropriate dosage regimen of antibiotics to prevent bacterial infection in implant dentistry. To determine effectiveness of different antibiotics regimens to prevent early infection after implant placement. A systematic review of all relevant studies addressing the use of antibiotic for dental implant surgery was carried-out. Implant groups not using antibiotics, were also analyzed. Primary outcomes were incidence of postoperative infection and frequency of implant failure due to infection. From 164 articles reviewed, 11 fulfilled the selection criteria representing 9472 placed implants. Regimens associated with the use of postoperative antibiotics showed a lower incidence of early infection (postoperative regimens $0 \%$, pre and postoperative regimens $0.22 \%$ and $0.53 \%$, long- and short-course, respectively $(P=0.275))$. Regarding failure due to infection, no differences between groups were found $(P=0.249)$. A trend favoring the use of postoperative antibiotic to prevent early infections was observed. Further studies should be carried out in order to provide evidence-based clinical guidelines for use of antibiotics in dental implant placement.
\end{abstract}

KEY WORDS: antibiotic prophylaxis, dental implants, systematic review, infection.

\section{INTRODUCTION}

High success rates of osseointegrated implants for teeth replacement has been well documented (Liddelow \& Klineberg, 2011). However, risk of failure is high during the first year after implant placement (Garlini et al., 2003; Rasmusson et al., 2005; Levin et al., 2006). Presence of bacterial biofilms, overheating, and surgical trauma are considered the main reasons of early implant failure (Heuer et al., 2011). Oral microorganisms play a key role in biomaterial associated infections, since implant surfaces are prone to be colonized during surgery (perioperative contamination) (Cortizo et al., 2012).
Infections around biomaterials are difficult to treat and require immediate implant removal. For this reason, efforts to avoid microorganism contamination have to be addressed (Esposito et al., 1998). Antibiotic prophylaxis seems to be appropriate in cleancontaminated surgery as implant placement procedure (Dent et al., 1997), where an infection rate in a range of $10 \%$ to $15 \%$ is expected (Resnik \& Misch, 2008). However, there is still debate about whether postoperative dental infections that lead to implant failure could be reduced with the use of antibiotics and aseptic surgical techniques. Moreover, the routine use of

Epi-Clin. MSc, Responsible Research, Center for Advanced Prosthodontics and Implant Dentistry (CRAI), University of Concepción, Concepcion, Chile.

* DDS, PhD, Director, Center for Advanced Prosthodontics and Implant Dentistry (CRAl), University of Concepción, Concepcion, Chile.

*** Pharm.D, MSc, Professor, Department of Public Health, Faculty of Medicine, Coordinator Chilean branch of the Iberoamerican Cochrane Network, Universidad Católica de la Santísima Concepción, Concepción, Chile.

**** MD, PhD, Professor, Department of Surgery, Faculty of Medicine, University of La Frontera, Temuco, Chile.

${ }_{* * * * * *}^{*}$ Center for Biomedical Research, Universidad Autónoma de Chile, Temuco, Chile. 
antibiotics could cause some adverse effects, from mild gastrointestinal symptoms to more serious hypersensitivity reactions (Esposito et al., 2008; Sharaf \& Dodson, 2011) as well as to contributing to the selection of antibiotic-resistant bacteria.

American Heart Association (AHA) (Wilson et al., 2008) and British Society of Antimicrobial Chemotherapy (BSAC) (Gould et al., 2006) guidelines propose the use of antibiotic prophylaxis before dental surgical procedures in patients with endocarditis or that are immunocompromised.

Antibiotics are also recommended in cases when surgery is performed in infected sites, in prolonged surgeries that affect mucosa membranes or when large foreign materials are placed (Kaiser, 1986; Anitua et al., 2009). Currently, no case-specific guidelines are available for the use of antibiotics in healthy patients with an indication for implant surgery (Mazzocchi et al., 2007). Additionally, it should be considered that most dental implants are located in previously compromised sites with a certain degree of infection (Nelson \& Thomas, 2010), which could be a main risk for infection and risk of implant failure. However, since implant failure is multifactorial, the major drawback of previous systematic reviews (SRs) was to consider it as a primary outcome.

In daily practice, dentists face the difficult choice of using or not using prophylactic antibiotics, applying general rules of risk-benefit analysis in order to decide. Although, several dosage regimens of antibiotics have been proposed (preoperative or postoperative both single or multiple doses, or preoperative followed by postoperative doses) (Ahmad \& Saad, 2012), there is no evidence available that fully supports the treatment choice. There are randomized clinical trials (Abu-Ta'a et al., 2008; Esposito et al., 2008; Anitua et al.; Caiazzo et al., 2011; Esposito et al., 2010a) that showed clear trends favoring the use of antibiotics, but these studies do not reach the conventional level of statistical significance. A metaanalysis (Esposito et al., 2010b) based on 4 randomized trials (1007 patients), reported that $2 \mathrm{~g}$ of amoxicillin administered 1 hour before surgery significantly reduces dental implant failure. However, authors cannot conclude if this regimen is more effective than postoperative administration. The major drawback in these systematic reviews was to consider implant failure as primary outcome, because this is a complex and multifactorial process, in which postoperative infection is one of several causes for implant failure. Therefore, when other important factors are not considered, it could lead to a biased estimation of the antibiotic's effect.
The present systematic review was carried out to address the question of determining the most safe and effective antibiotic dosage regimen to prevent early postoperative peri-implant infection.

\section{MATERIAL AND METHOD}

Selection criteria for studies. Type of studies and participants: All relevant study designs addressing questions related to the use of antibiotics for dental implant surgery were included, as well as comparisons between different dosage regimens with or without antibiotics (placebo or no intervention). Participants were adults $\geq 18$ years, partial or totally edentulous, who had undergone dental implant surgery.

Discussion articles, letters to the editor, clinical guidelines and systematic reviews were excluded from this review. Additionally, studies were not considered that had issues unrelated to this topic, or with patients who did not meet one or more criteria for inclusion, or articles from which an abstract is unavailable.

\section{Types of interventions}

1. Use of antibiotics in one or more doses: a) Preoperative, b) Postoperative, c) Pre-and postoperative.

2. Without antibiotics or with placebo.

\section{Types of outcome}

Outcomes were grouped by regimen and time as follows:

1. Preoperative beta-lactam antibiotic or alternative, any dose.

2. Preoperative followed by postoperative betalactam antibiotic or alternative, any short course dose ( $<5$ days).

3. Preoperative followed by postoperative betalactam antibiotic or alternative, any long course dose ( $\geq 5$ days).

4. Postoperative beta-lactam antibiotic or alternative, any dose.

5. No beta-lactam antibiotic, nor alternative antibiotic lor placebo used.

Primary outcomes for this study were the incidence of early infection and frequency of implant failure due to infection. 
Secondary outcomes were the frequency of antibiotic adverse effects: gastrointestinal tract reactions and drug hypersensitivity reactions.

Literature Search Strategy. A search was carried out in March 2012, in MEDLINE, CENTRAL, BIREME Library, COCHRANE LIBRARY, LILACS, and SCIELO databases, without language and date restrictions.

This search used MeSH terms and free words, using the following: "antibiotic prophylaxis"[MeSH Terms] OR antibiotic prophylaxis [Text Word] OR "Anti-Bacterial Agents"[Mesh]; "dental implants"[MeSH Terms] OR dental implant [Text Word] "dental prosthesis"[MeSH Terms] OR dental prosthesis [Text Word]; "Surgical Procedures, Operative"[Mesh]).
Additionally, other resources were considered in the search, i.e. reference list of primary studies and review articles, database of clinical trials registry and conference proceeding (if available).

Review Methodology. Article selection and data extraction for selected articles.

In the first stage, two researchers independently inspected titles and abstracts of all reports. Full reports were obtained from all articles potentially selected and/ or with insufficient data in the title or abstract. The second stage consisted in independently extracted data from selected trials. Any disagreement in both stages was resolved by discussion between the primary two

Table I. Methodological score quality designed for the systematic revision of primary studies.

\begin{tabular}{|c|c|}
\hline & Assigned score \\
\hline \multicolumn{2}{|l|}{ Item 1: Study design } \\
\hline Multicenter clinical trial & 12 \\
\hline Random controlled clinical trial & 9 \\
\hline Clinical trial (without blind or single-blind, without randomization ${ }^{\mathrm{D}}$ & 6 \\
\hline Concurrent or retrospective cohort & 4 \\
\hline Historical or retrospective cohort & 3 \\
\hline Cross-sectional & 1 \\
\hline Series of cases & 1 \\
\hline \multicolumn{2}{|l|}{ Item 2: Studied population $\mathrm{x}$ justification factor ${ }^{\mathrm{c}}$} \\
\hline$\geq 201$ & 6 or 12 \\
\hline $151-200$ & 5 or 10 \\
\hline $101-150$ & 4 or 8 \\
\hline $61-100$ & 3 or 6 \\
\hline $31-60$ & 2 or 4 \\
\hline$\leq 30$ & 1 or 2 \\
\hline \multicolumn{2}{|l|}{ Item 3: Used methodology employed } \\
\hline \multicolumn{2}{|l|}{ Objective } \\
\hline Clear and specific objectives are posed & 3 \\
\hline Vague objectives are posed & 2 \\
\hline No objectives are posed & 1 \\
\hline \multicolumn{2}{|l|}{ Design } \\
\hline Employed design is mentioned and justified & 3 \\
\hline Employed design is mentioned & 2 \\
\hline Employed design is neither mentioned not justified & 1 \\
\hline \multicolumn{2}{|l|}{ Sample selection criteria } \\
\hline Inclusion and exclusion criteria are described & 3 \\
\hline Inclusion or exclusion criteria are described & 2 \\
\hline No selection criteria are described & 1 \\
\hline \multicolumn{2}{|l|}{ Sample size } \\
\hline Sample employed is justified & 3 \\
\hline Sample employed is not justified & 1 \\
\hline \multicolumn{2}{|l|}{ Final score } \\
\hline Item $1+$ (item $2 \times$ justification factor) + item 3 & $6-36$ \\
\hline
\end{tabular}

$a=$ Includes clinical trials with restricted randomization and quasi-experimental studies.

$\mathrm{b}=$ Includes experimental studies (before and after).

$c=$ Justification factor: 2 justifies the sample and 1 does not justifies it. 
researchers, and in the case of unresolved issues, a third reviewer was consulted.

Methodological quality assessment. Methodological quality of all studies that fulfilled the inclusion criteria were analyzed using a validated and reliable methodological quality scale (facade validity, content validity and inter-observer reliability) composed of 3 items: design, sample size, and methodological aspects (Manterola et al., 2003, 2005a, 2005b, 2006, 2009) (Table I). The final score was the sum of the 3 items showing a range between 6 and 36 points, with a quality cut-off value of 18 points. Two reviewers independently applied the scale to the selected articles. Differences that might exist were resolved by consensus.

Statistical analysis. Data was analyzed using descriptive statistics (mean, weighted means, standard deviation and minimum and maximum values). Inferential statistic such as non-parametric $U$ MannWhitney or Kruskal Wallis tests were used to compare the weighted means of treatment groups and mean methodological quality of the primary studies. Groups were considered significantly different when $\mathrm{P} \leq 0.05$.

Subgroups planned for analysis were: with or without bone substitute, flap vs. flapless procedure, insertion torque ( $\geq 35 \mathrm{Ncm}$ vs. $<34 \mathrm{Ncm}$ ), upper jaw vs. lower jaw and immediate vs. delayed implant.

\section{RESULTS}

Literature Search. The search criteria identified 164 articles, from which, based on title and abstract and full text, 34 were selected, and 14 fulfilled the inclusion criteria. From these, three studies were excluded, due to duplicate information ( $n=1)$ (Laskin et al., 2000), and because the data was not adequate to carry out an appropriate analysis $(n=2)$ (Dent et al.; Morris et al., 2004); thus, 11 articles were included in this study (Fig. 1).

Study Description. Table II gives a description of the studies selected. A total of 23 groups of implants were obtained, which represent 9472 implants placed (Table III). Overall, most studies considered early infection as an outcome with a mean follow-up period of $67.04 \pm 19.39$ days (Table IV).

According to the items of the applied methodological quality scale, $70 \%$ of groups came from

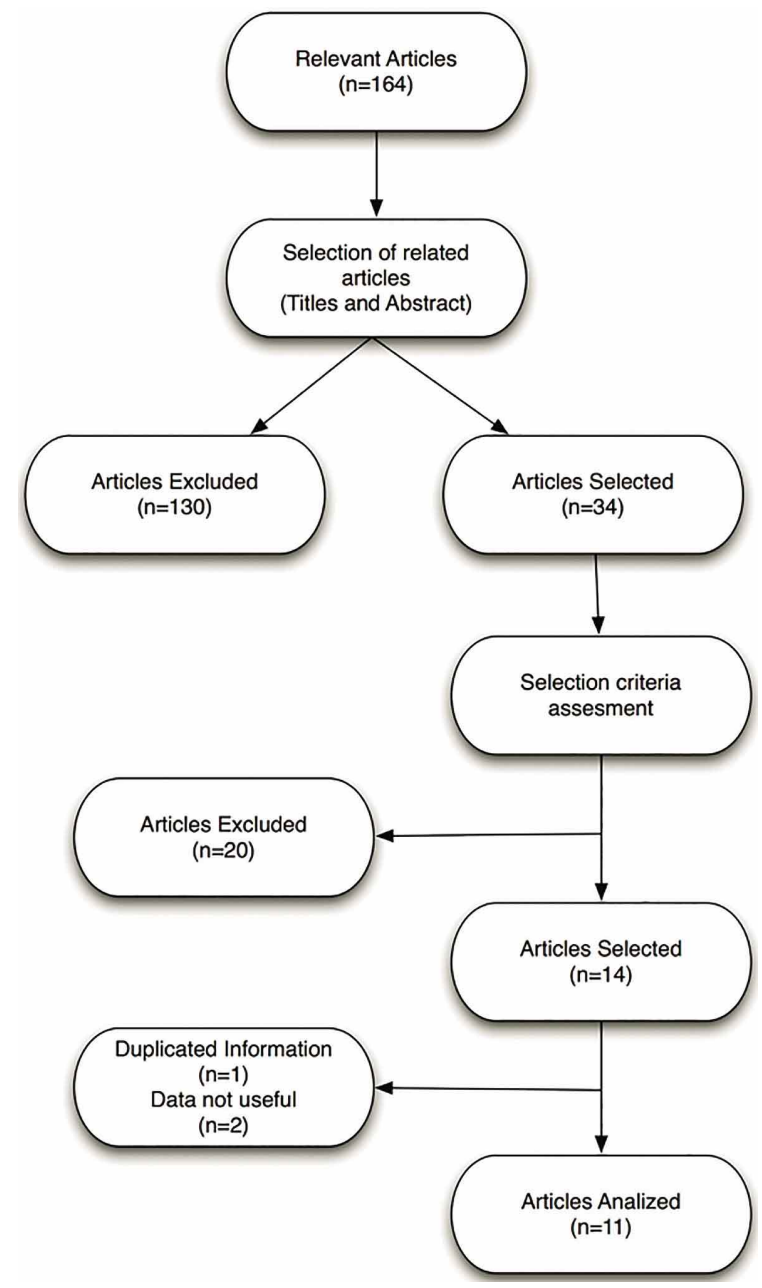

Fig. 1. Study flow chart.

multicenter randomized clinical trials $(n=10)$ and randomized clinical trials $(n=6) .74 \%$ stated clear and specific aims, $52.2 \%$ reported the selection criteria for the patients, and only $30 \%$ justified the sample size used (Table V).

The mean score for the primary studies $(n=11)$ was $23.5 \pm 7.5$, with a minimum score of 13 and a maximum of 36 . $34 \%$ were below 18 points (quality cut-off point). Grouped by type of therapy, mean scores showed values above the cut-off point. There were no significant differences when comparing scores from the therapy groups (Chi-Square 5.878, $\mathrm{P}=0.275$ ) (Table $\mathrm{VI})$.

The inter-observer reliability obtained for the quality methodological scale applied was high (Cohen's Kappa $=0.8693$ ). 
Table II. Description of selected studies.

\begin{tabular}{|c|c|c|c|}
\hline \multirow{2}{*}{\multicolumn{4}{|c|}{$\begin{array}{ccc}\text { Author } & \text { Antibiotic } & \text { Dosage } \\
\text { Comparison one antibiotic } \text { regimen vs. no antib iotic }\end{array}$}} \\
\hline & & & \\
\hline \multirow[t]{2}{*}{$\begin{array}{l}\text { Abu-Ta'a et al. } \\
(2008)\end{array}$} & Amoxicillin & $\begin{array}{l}1 \mathrm{~g} \mathrm{P} . O .1 \mathrm{~h} \text { preoperatively and } 500 \mathrm{mg} 4 \text { times/day for } 2 \\
\text { days postoperatively }\end{array}$ & $n=187$ \\
\hline & No Antibiotic & -------- & $n=119$ \\
\hline \multirow{3}{*}{$\begin{array}{l}\text { Anitua et al. } \\
(2009)\end{array}$} & Amoxicillin & 2 g P.O. 1 hour preoperatively & $n=52$ \\
\hline & Identical Placebo & & $n=53$ \\
\hline & No antibiotic & ----- & $n=29$ \\
\hline \multirow{2}{*}{$\begin{array}{l}\text { Esposito et al. } \\
(2008)\end{array}$} & Amoxicillin & 2 g P.O. 1 hour preoperatively & $n=341$ \\
\hline & Identical Placebo & & $n=355$ \\
\hline \multirow{2}{*}{$\begin{array}{l}\text { Esposito et al. } \\
\text { (2010a) }\end{array}$} & Amoxicillin & 2 g P.O. 1 hour preoperatively & $n=489$ \\
\hline & Identical Placebo & & $n=483$ \\
\hline \multirow[t]{2}{*}{$\begin{array}{l}\text { Gynther et al. } \\
\text { (1998) }\end{array}$} & Penicillin V & $\begin{array}{l}1 \mathrm{~g} \mathrm{P} . \mathrm{O} .1 \mathrm{~h} \text { preoperatively and } 1 \mathrm{~g} 3 \text { times/day for } 10 \text { days } \\
\text { postoperatively }\end{array}$ & $n=790$ \\
\hline & No antibiotic & & $n=664$ \\
\hline \multicolumn{4}{|c|}{ Comparison of at least two antibiotic regimens } \\
\hline \multirow[t]{2}{*}{$\begin{array}{l}\text { Binahmed et al. } \\
\text { (2005) }\end{array}$} & $\begin{array}{l}\text { Penicillin G or Clyndamicin or } \\
\text { Penicillin V }\end{array}$ & $\begin{array}{l}\text { Slowly } 1.000 .000 \text { unit (Pen G) IV or } 600 \mathrm{mg} \text { (Clynda) IV } \\
\text { preoperatively or } \\
1 \mathrm{~g}(\text { Pen V) P.O. } 1 \mathrm{~h} \text { preoperatively or } 600 \mathrm{mg} \text { (Clynda) P.O. } \\
1 \mathrm{~h} \text { preoperatively }\end{array}$ & $n=445$ \\
\hline & Penicillin V or Clyndamycin & $\begin{array}{l}300 \mathrm{mg} \text { (Pen V) P.O. } 4 \text { times/day for } 7 \text { days or } \\
150 \mathrm{mg} \text { (Clynda) P.O. } 3 \text { times/day for } 7 \text { days }\end{array}$ & $n=302$ \\
\hline \multirow[t]{2}{*}{$\begin{array}{l}\text { Kashani et al. } \\
(2005)\end{array}$} & Penicillin V & $\begin{array}{l}2 \mathrm{~g} \text { P.O. } 2 \text { times/day for } 1 \text { week posto peratively, the first } \\
\text { dose being given1 hour preoperatively }\end{array}$ & $n=2236$ \\
\hline & Penicillin V & $\begin{array}{l}2 \text { g P.O. } 1 \text { hour preoperatively and one dose postoperatively } \\
\text { the same day }\end{array}$ & $n=785$ \\
\hline \multirow[t]{2}{*}{$\begin{array}{l}\text { Karaky et al. } \\
(2011)\end{array}$} & $\begin{array}{l}\text { Amoxicillin } \\
\text { Amoxicillin }\end{array}$ & $\begin{array}{l}2 \mathrm{~g} \mathrm{P.O.} 1 \text { hour preoperatively } \\
2 \mathrm{~g} \mathrm{P.O.} 1 \text { hour preoperatively and postoperative doses of } \\
500 \mathrm{mg} 3 \text { times/day for } 5 \text { days }\end{array}$ & $\begin{array}{l}n=210 \\
n=266\end{array}$ \\
\hline & \multicolumn{3}{|c|}{ Comparison of 3 regimens including a group without antib iotics } \\
\hline \multirow[t]{2}{*}{$\begin{array}{l}\text { Caiazzo et al. } \\
(2011)\end{array}$} & $\begin{array}{l}\text { Amoxicillin } \\
\text { Amoxicillin }\end{array}$ & $\begin{array}{l}2 \mathrm{~g} \text { P.O. } 1 \text { hour preoperatively } \\
2 \mathrm{~g} \text { P.O } 1 \text { hour preoperatively and } 1 \mathrm{~g} 2 \text { times/day for } 7 \text { days } \\
\text { postoperatively }\end{array}$ & $\begin{array}{l}n=35 \\
n=36\end{array}$ \\
\hline & Amoxicillin & 1 g P.O. 2 times/day postoperatively continued for 1 week & $n=48$ \\
\hline \multicolumn{4}{|c|}{ Without antibiotics } \\
\hline $\begin{array}{l}\text { Mazzocchi et } \\
\text { al. (2007) }\end{array}$ & No antibiotic & ----- & $n=736$ \\
\hline \multicolumn{4}{|c|}{ One antibiotic regimen } \\
\hline $\begin{array}{l}\text { Rizzo et al. } \\
(2010)\end{array}$ & $\begin{array}{l}\text { Amoxicillin or Ampicillin or } \\
\text { Azithromicin/Clarithromycin }\end{array}$ & $\begin{array}{l}2 \mathrm{~g}(\text { Amoxi) P.O. 1h preoperatively+1g P.O. } 6 \mathrm{~h} \text { after+1g } \\
\text { P.O. 18h after } \\
2 \mathrm{~g}(\text { Ampi) IM/IV1h preoperatively+ } 1 \mathrm{~g} \text { IM/IV } 6 \mathrm{~h} \text { after+1g } \\
\text { IM/IV 18h after or } \\
500 \mathrm{mg} \text { (Azithro/Clari) P.O. } 1 \mathrm{~h} \text { preoperatively+500mg P.O. } \\
6 \mathrm{~h} \text { after+500mg P.O. } 18 \mathrm{~h} \text { after }\end{array}$ & $n=521$ \\
\hline
\end{tabular}

\section{Clinical outcome assessment}

Postoperative early infection. Overall, postoperative early infection (PEI) presented a low incidence. Groups using only preoperative antibiotics showed an incidence of $2.79 \%$ and when no antibiotic was administered PEI presented $3.06 \%$. Groups associated with postoperative antibiotic treatment showed a lower incidence. In the case of pre and postoperative regimens, the incidences of early infection for long and short course were $0.22 \%$ and $0.53 \%$, respectively. No infection was reported when only postoperative antibiotic treatment was applied (Table VII). However, no statistically significant differences were found between groups (Chi-Square 5.133, $\mathrm{P}=0.275)$. 
Table III. Distribution of studies according to therapies and number of implant placed.

\begin{tabular}{lcccc}
\hline Antibiotic (AB) Regimen & n Groups & \% & n implants & \% \\
\hline Preope. AB & 6 & 26.09 & 1572 & 16.60 \\
Pre and post long-course & 5 & 21.74 & 3630 & 38.32 \\
Pre and post short-course & 3 & 13.04 & 1493 & 15.76 \\
Postope. AB & 2 & 8.70 & 338 & 3.57 \\
Without AB & 7 & 30.43 & 2439 & 25.75 \\
Total & 23 & 100 & 9472 & 100 \\
\hline
\end{tabular}

Table IV. Follow-up period for the variable infection.

\begin{tabular}{llc}
\hline Antibiotic (AB) Regimen & $\mathbf{n}$ implants & $\begin{array}{c}\text { Follow-up in Days for infection Mean } \\
\text { (min- max) }\end{array}$ \\
\hline Preope. AB & 1572 & $74.6(14-180)$ \\
Pre and post long-course & 3630 & $73.4(7-150)$ \\
Pre and post short-course & 1493 & $83.3(10-180)$ \\
Postope. AB & 338 & $75(60-90)$ \\
Without AB & 2439 & $28.9(7-90)$ \\
\hline
\end{tabular}

Table V. Classification of studies according to therapies and methodological aspects.

\begin{tabular}{lcccc}
\hline \multicolumn{1}{c}{ Antibiotic (AB) Regimen } & $\begin{array}{c}\text { Design } \\
\text { RC/CT/RCT/ } \\
\text { MRCT }\end{array}$ & $\begin{array}{c}\text { Clear and } \\
\text { specific aims } \\
\text { Yes/total }\end{array}$ & $\begin{array}{c}\text { Selection Criteria } \\
\text { (inclusion and exclusion) } \\
\text { Yes/total }\end{array}$ & $\begin{array}{c}\text { Sample Justification } \\
\text { Yes/total }\end{array}$ \\
\hline Preope. AB & $0 / 0 / 2 / 4$ & $3 / 6$ & $5 / 6$ & $3 / 6$ \\
Pre and post long-course & $2 / 0 / 2 / 1$ & $4 / 5$ & $2 / 5$ & $1 / 5$ \\
Pre and post short-course & $2 / 0 / 1 / 0$ & $3 / 3$ & $1 / 3$ & $0 / 3$ \\
Postope. AB & $0 / 1 / 0 / 1$ & $2 / 2$ & $1 / 2$ & $1 / 2$ \\
Without AB & $2 / 0 / 1 / 4$ & $5 / 7$ & $3 / 7$ & $2 / 7$ \\
\hline
\end{tabular}

$\mathrm{RC}=$ Retrospective Cohort; CT= Clinical Trial not randomized; RCT= Randomized Clinical Trial; MRCT=Multicenter Randomized Clinical Trial.

Table VI. Comparison of average score of studies according to therapy groups and $95 \% \mathrm{Cl}$ of the mean.

\begin{tabular}{lcc}
\hline \multicolumn{1}{c}{ Antibiotic (AB) Regimen } & n Studies & Score mean \\
\hline Preope. AB & 6 & 28.83 \\
Pre and post long-course & 5 & $23.59,34.07$ \\
& & 20.6 \\
Pre and post short-course & 3 & $16.42,24.78$ \\
& & 19.0 \\
Postope. AB & 2 & $14.90,23.09$ \\
Without AB & & 22.5 \\
& 7 & $19.43,25.57$ \\
& & 25.43 \\
\end{tabular}

Table VII. Description of primary outcomes and according to therapy groups.

\begin{tabular}{lcc}
\hline Antibiotic (AB) Regimen & $\mathbf{n}$ implants & $\begin{array}{c}\text { Incidence of postoperative infection } \\
\text { \% (min - max) }\end{array}$ \\
\hline Preope. AB & 1572 & $2.79(0-11.54)$ \\
Pre and post long-course & 1394 & $0.22(0-0.38)$ \\
Pre and post short- course & 187 & 0.53 \\
Postope. AB & 338 & 0 \\
Without AB & 2439 & $3.06(0-11.32)$ \\
\hline
\end{tabular}


Table VIII. Frequency of implant failure due infection.

\begin{tabular}{lcc}
\hline Antibiotic (AB) Regimen & n implants & $\begin{array}{c}\text { Frequency of implant failure due infection } \\
\text { (min - max) }\end{array}$ \\
\hline Preope. AB & 1310 & $0.89(0-3)$ \\
Pre and post long-course & 338 & 0 \\
Postope. AB & 48 & 0 \\
Without AB & 1722 & $1.86(0-4)$ \\
\hline
\end{tabular}

Table IX. Description of frequencies of antibiotic adverse effects.

\begin{tabular}{lcccc}
\hline $\begin{array}{l}\text { Antibiotic (AB) } \\
\text { Regimen }\end{array}$ & n participants & $\begin{array}{c}\text { Frequency Gastrointestinal } \\
\text { side effects }\end{array}$ & n Participants & $\begin{array}{c}\text { Frequency } \\
\text { Hypersensitivity reaction }\end{array}$ \\
\hline Preope. AB & 508 & $0.31(0-1)$ & 435 & 0 \\
Pre and post long- & 98 & 0 & 25 & 0 \\
Pre and post short- & 20 & --- & 0 & 0 \\
Postope. AB & 113 & 0 & 25 & 0 \\
Without AB & 457 & 0 & 457 & 0 \\
\hline
\end{tabular}

Frequency of implant failures due to infection. A very low frequency of implant failure due infection was observed. See Table VIII. No statistically significant difference was observed (Chi-Square 4.118, $P=0.249$ ). Table VIII considered only implant groups that reported infection incidence that provoked implant failure.

Gynther et al. (1998), Karaky et al. (2011) and Anitua et al. were excluded due to absence of implant failure causes and Kashani et al. (2005), because these studies did not report infection incidence.

Antibiotic Adverse effects. Overall, antibiotics were well tolerated by patients (Table IX). No participant presented hypersensitivity reactions. People using prophylaxis antibiotics had very low frequency of gastrointestinal effects. No statistically significant differences between groups were observed (ChiSquare 2.250, $P=0.690$ ).

\section{DISCUSSION}

Systematic review (SR) of literature is a useful tool to analyze available therapeutic evidence that supports or does not support the use of antibiotics in implant placement protocol.

Previous systematic reviews have been published on this topic. Esposito et al. (2010b), published a Cochrane systematic review based on 4 $\mathrm{RCT}$, concluding that preoperative antibiotic therapy significantly reduces early failure of dental implants (RR $=0.40(95 \% \mathrm{Cl} 0.19$ to 0.84$))$ placed in ordinary conditions. However, this result should be taken with caution since the risk of implant failure was 2.5 times lower using antibiotics, which is clinically meaningful, but the confidence interval suggests the true impact of antibiotics could be close to 1 . This means that there is a chance that this therapy is not clinically significant. On the other hand, considering implant failure present multifactorial causes, important predictors of implant failure could not be analyzed due to the small number of selected studies. Moreover, authors have stated that there is still uncertainty about the effectiveness of the adjunctive pre- and postoperative therapy.

A similar SR of randomized clinical trials reported by Sharaf \& Dodson and a SR of different design studies by Sharaf et al. (2011) agrees with Esposito et al. (2010b), reporting that preoperative antibiotic regimen reduces the rate of early implant failure. Also, authors added that a preoperative and postoperative antibiotic regimen is effective to prevent early failure.

However, the major drawback of the latter SR was to consider implant failure as a primary outcome, regarding it as an effectiveness indicator of antibiotic treatment. The effects of antibiotics are associated with the infection-risk in the immediate postoperative period. This period is considered between the fifth and tenth day after surgery, therefore, the correct outcome should be incidence of early postoperative infection. In the present study, postoperative infection and failure due to infection were considered as primary outcomes.

On the other hand, implant failure is a complex and multifactorial process, in which postoperative infection is one of the several important causes of early 
implant failure (Sakka et al., 2012). Therefore, when other important factors are not considered, a biased estimation of antibiotic effects can take place.

This SR did not find statistically significant differences in any of the comparisons of the different therapy groups. However, these results allowed the description of trends from a clinical point of view.

Although infection incidence was low in all studied groups, including the group not using antibiotics, there is a clear trend towards regimens that include postoperative antibiotics to avoid early PEI. The frequency of failures due to infection was not described in every study, making interpretation difficult. Studies that reported this outcome described low frequencies for all therapies including in Groups without the use of antibiotic therapy.

Based on these results, and considering that most implants are placed in sites that have previously been chronically infected, leading to the possibility that the apparently healed bone and asymptomatic sites following extraction may harbor persistent microbial species (Nelson \& Thomas), it seems sensible to prevent early PEI in order to obtain successful treatment.

However, use of antibiotics in oral surgery should be limited, and reserved for patients with increased risk of infection (e.g. patients with health condition that favors infection, and patients with previously compromised sites with a high degree of contamination) and/or when is necessary to carry out an extensive surgical procedure. Also, clinicians must consider the adequate dosage regimen that minimizes the risk of antibiotic resistance, which means high doses and/or during a short period (Peterson, 1990). According to protocol by Resnik \& Misch, local, systemic, surgical and procedural factors should be considered before making the decision to use antibiotics to prevent PEI.

Regarding the frequencies of adverse effects, antibiotics were well tolerated and no major adverse effects were reported during the follow-up period. However, primary studies did not report a formal assessment, nor a description of how the adverse effects were recorded.

Limitation of the study. In the studies included in this $\mathrm{SR}$, heterogeneity was observed in factors affecting success rates of implants. Several authors (Gynther et al.; Binahmed et al., 2005; Abu-Ta'a et al.; Anitua et al.; Esposito et al., 2008; Esposito et al., 2010a; Rizzo et al., 2010; Karaky et al.) have reported the use of pre and/or post operatory oral antiseptic. Abu-Ta'a et al. described the application of high-end asepsis policy. Most of the studies stated that procedures were performed by surgeons with at least 5 years experience (Kashani et al.; Mazzocchi et al.; Rizzo et al.; Karaky et al.) while in others, the years of experience was not reported (Gynther et al.; Abu-Ta'a et al.; Caiazzo et al.). In most of the studies, implant characteristics were not stated, some indicated implant brand (Gynther et al.; Kashani et al.; Mazzocchi et al.; Esposito et al., 2008; Rizzo et al.; Karaky et al.). Some studies excluded patients who required bone augmentation procedures (Binahmed et al.; Esposito et al., 2008; Esposito et al., 2010a) as well as patients with hard and soft bone quality (Anitua et al.).

Confounding factors related to failures were reported by Abu-Ta'a et al. showing that failures occurred in patients with parafunctions, blood clotting, and those who were heavy smokers. Additionally, groups from an Anitua et al. study could introduce a singular bias since all participants received implants humidified with plasma rich growth factor (PRGF). PRGF may positively favor bone regeneration and soft tissue healing, which could mask the real antibiotic effect over implant survival (Anitua, 1999, 2001).

In the present study, it was originally planned to investigate the possible influence of the predictor and confounding factors on implant failure, but in view of the scarce information about these variables, this analysis was not performed.

Suggestions for further research. Strict adherence to the Consolidated Standards of Reporting Trials (CONSORT statement) (Moher et al., 2012) for clinical trials as well as the Strengthening the Reporting of Observational studies in Epidemiology (STROBE statement) (von Elm et al., 2007) for observational studies, would improve the reporting and conduct of future research. Thus, the reports will have adequate information and data extraction for complete systematic reviews and for, performing required analysis.

Also, for further research, it seems to be reasonable to report the degree of site contamination as an outcome, which should be essential for choosing an antibiotics regimen as a prophylaxis or therapeutic prescription. Active infection in the area of planned surgery has a therapeutic indication (Lawler et al., 2005; Florman \& Nichols, 2007). 


\section{CONCLUSION}

Despite the study limitations, antibiotic prophylaxis seems to yield a favorable effect, particularly when used in regimens considering postoperative antibiotics. However, further double-blind randomized clinical trials are needed to establish a proper patient-specific prophylaxis regimen (suggested design in Table X) in order to provide evidence-based clinical guidelines for using antibiotics for dental implant placement.

Table X. Suggested design for further research.

\begin{tabular}{|c|c|}
\hline \multirow[t]{3}{*}{ Method } & $\begin{array}{l}\text { Randomized clinical trial, double blind with duration of minimum } 4 \\
\text { months. }\end{array}$ \\
\hline & Multicentric trial. \\
\hline & $\begin{array}{l}\text { Subgroups: Timing of implant placement, use of bone substitute, } \\
\text { surgical technique (flap or flapless), degree of infection. }\end{array}$ \\
\hline Participants & $\begin{array}{l}\text { People requiring implant placement, } \\
n=13.414 \text { dental implants }\end{array}$ \\
\hline \multirow[t]{3}{*}{ Intervention } & Pre operative dose. \\
\hline & Pre and postoperative dose short-course. \\
\hline & Placebo. \\
\hline \multirow[t]{3}{*}{ Outcomes } & Incidence of early infection. \\
\hline & Need of additional postoperative antibiotic dose. \\
\hline & Early implant failure (has to be removed) due to infection. \\
\hline
\end{tabular}

ASENJO-LOBOS, C.; JOFRE, J.; CORTES, M. \& MANTEROLA, C. Uso de antibióticos en la cirugía de implantes dentales: una decisión basada en la evidencia desde la revisión sistemática. Int. J. Odontostomat., 9(1):137147, 2015.

RESUMEN: Todavía se mantiene el integorrante acerca de si las infecciones postoperatorias y el fracaso de los implantes se pueden reducir con el uso de antibióticos. Especialmente, cuando su uso rutinario puede causar efectos adversos y puede contribuir al desarrollo de bacterias resistentes a los antibióticos. Por otra parte, no hay consenso en cuanto al régimen de dosificación apropiado de antibióticos para prevenir la infección bacteriana en los implantes dentales. Para determinar la efectividad de los diferentes regímenes de antibióticos destinados a prevenir la infección temprana después de la colocación del implante, se llevó a cabo una revisión sistemática de todos los estudios pertinentes sobre el uso de antibióticos para la cirugía del implante dental. También fueron analizados grupos de pacientes en los que se colocaron implantes sin el uso de antibióticos. Los resultados iniciales demostraron la existencia de infección postoperatoria y el fracaso del implante debido a la infección. De 164 artículos revisados, 11 cumplieron con los criterios de selección, representando un total de 9.472 implantes colocados. Estudios asociados con el uso de antibióticos postoperatorios mostraron una menor incidencia de infección temprana (regímenes postoperatorios $0 \%$, regímenes pre y postoperatoria $0,22 \%$ y $0,53 \%$, a largo y corto plazo, respectivamente $(P=$ $0,275)$ ). En cuanto al fracaso debido a la infección, no se encontraron diferencias entre los grupos $(p=0,249)$. Se observó una tendencia a favor del uso de antibióticos para prevenir infecciones postoperatorias tempranas. Nuevos estudios deben llevarse a cabo con el fin de proporcionar directrices clínicas, basadas en la evidencia, para el uso de antibióticos en la colocación del implante dental.

PALABRAS CLAVE: profilaxis antibiótica, implantes dentales, revisión sistemática, infección.

\section{REFERENCES}

Abu-Ta'a, M.; Quirynen, M.; Teughels, W. \& van Steenberghe, D. Asepsis during periodontal surgery involving oral implants and the usefulness of peri-operative antibiotics: a prospective, randomized, controlled clinical trial. J. Clin. Periodontol., 35(1):58-63, 2008. 
Ahmad, N. \& Saad, N. Effects of antibiotics on dental implants: a review. J. Clin. Med. Res., 4(1):1-6, 2012.

Anitua, E.; Aguirre, J. J.; Gorosabel, A.; Barrio, P.; Errazquin, J. M.; Román, P.; Pla, R.; Carrete, J.; de Petro, J. \& Orive, G. A multicentre placebo-controlled randomised clinical trial of antibiotic prophylaxis for placement of single dental implants. Eur. J. Oral Implantol., 2(4):283-92, 2009.

Anitua, E. Plasma rich in growth factors: preliminary results of use in the preparation of future sites for implants. Int. J. Oral Maxillofac. Implants, 14(4):529-35, 1999.

Anitua, E. The use of plasma-rich growth factors (PRGF) in oral surgery. Pract. Proced. Aesthet. Dent., 13(6):48793, 2001.

Binahmed, A.; Stoykewych, A. \& Peterson, L. Single preoperative dose versus long-term prophylactic antibiotic regimens in dental implant surgery. Int. J. Oral Maxillofac. Implants, 20(1):115-7, 2005.

Caiazzo, A.; Casavecchia, P.; Barone, A. \& Brugnami, F. A pilot study to determine the effectiveness of different amoxicillin regimens in implant surgery. J. Oral Implantol., 37(6):691-6, 2011.

Cortizo, M.C.; Oberti, T. G.; Cortizo, M. S.; Cortizo, A. M. \& Fernández Lorenzo de Mele, M. A. Chlorhexidine delivery system from titanium/polybenzyl acrylate coating: evaluation of cytotoxicity and early bacterial adhesion. J. Dent., 40(4):329-37, 2012.

Dent, C. D.; Olson, J. W.; Farish, S. E.; Bellome, J.; Casino, A. J.; Morris, H. F. \& Ochi, S. The influence of preoperative antibiotics on success of endosseous implants up to and including stage II surgery: a study of 2,641 implants. J. Oral Maxillofac. Surg., 55(12 Suppl. 5):19-24, 1997.

Esposito, M.; Hirsch, J. M.; Lekholm, U. \& Thomsen, P. Biological factors contributing to failures of osseointegrated oral implants. (II). Etiopathogenesis. Eur. J. Oral Sci., 106(3):721-64, 1998.

Esposito, M.; Cannizzaro, G.; Bozzoli, P.; Checchi, L.; Ferri, V.; Landriani, S.; Leone, M.; Todisco, M.; Torchio, C.; Testori, T.; Galli, F. \& Felice, P. Effectiveness of prophylactic antibiotics at placement of dental implants: a pragmatic multicentre placebo-controlled randomised clinical trial. Eur. J. Oral Implantol., 3(2):135-43, 2010a.

Esposito, M.; Cannizzaro, G.; Bozzoli, P.; Consolo, U.; Felice, P.; Ferri, V.; Landriani, S.; Leone, M.; Magliano, A.; Pellitteri, G.; Todisco, M. \& Torchio, C. Efficacy of prophylactic antibiotics for dental implants: a multicentre placebo-controlled randomised clinical trial. Eur. J. Oral Implantol., 1(1):23-31, 2008.
Esposito, M.; Worthington, H. V.; Loli, V.; Coulthard, P. \& Grusovin, M. G. Interventions for replacing missing teeth: antibiotics at dental implant placement to prevent complications. Cochrane Database Syst. Rev., (7):CD004152, $2010 \mathrm{~b}$.

Florman, S. \& Nichols, R. L. Current approaches for the prevention of surgical site infections. Am. J. Infect. Dis., 3(1):51-61, 2007.

Garlini, G.; Bianchi, C.; Chierichetti, V.; Sigurtà, D.; Maiorana, C. \& Santoro, F. Retrospective clinical study of Osseotite implants: zero- to 5-year results. Int. J. Oral Maxillofac. Implants, 18(4):589-93, 2003.

Gould, F. K.; Elliott, T. S.; Foweraker, J.; Fulford, M.; Perry, J. D.; Roberts, G. J.; Sandoe, J. A.; Watkin, R. W. \& Working Party of the British Society for Antimicrobial Chemotherapy. Guidelines for the prevention of endocarditis: report of the Working Party of the British Society for Antimicrobial Chemotherapy. J. Antimicrob. Chemother., 57(6):1035-42, 2006.

Gynther, G. W.; Köndell, P. A.; Moberg, L. E. \& Heimdahl, A. Dental implant installation without antibiotic prophylaxis. Oral Surg. Oral Med. Oral Pathol. Oral Radiol. Endod., 85(5):509-11, 1998.

Heuer, W.; Stiesch, M. \& Abraham, W. R. Microbial diversity of supra- and subgingival biofilms on freshly colonized titanium implant abutments in the human mouth. Eur. J. Clin. Microbiol. Infect. Dis., 30(2):193-200, 2011.

Kaiser, A. B. Antimicrobial prophylaxis in surgery. N. Engl. J. Med., 315(18):1129-38, 1986.

Karaky, A. E.; Sawair, F. A.; Al-Karadsheh, O. A.; Eimar, H. A.; Algarugly, S. A. \& Baqain, Z. H. Antibiotic prophylaxis and early dental implant failure: a quasi-random controlled clinical trial. Eur. J. Oral Implantol., 4(1):31-8, 2011.

Kashani, H.; Dahlin, C. \& Alse'n, B. Influence of different prophylactic antibiotic regimens on implant survival rate: a retrospective clinical study. Clin. Implant Dent. Relat. Res., 7(1):32-5, 2005.

Laskin, D. M.; Dent, C. D.; Morris, H. F.; Ochi, S. \& Olson, J. $W$. The influence of preoperative antibiotics on success of endosseous implants at 36 months. Ann. Periodontol., 5(1):166-74, 2000.

Lawler, B.; Sambrook, P. J. \& Goss, A. N. Antibiotic prophylaxis for dentoalveolar surgery: is it indicated? Aust. Dent. J., 50(4 Suppl. 2):S54-9, 2005.

Levin, L.; Sadet, P. \& Grossmann, Y. A retrospective evaluation of 1,387 single-tooth implants: a 6-year followup. J. Periodontol., 77(12):2080-3, 2006. 
Liddelow, G. \& Klineberg, I. Patient-related risk factors for implant therapy. A critique of pertinent literature. Aust. Dent. J., 56(4):417-26, 2011.

Manterola, C.; Pineda, V.; Vial, M.; Losada, H. \& Muñoz, S. Revisión sistemática de la literatura. Propuesta metodológica para su realización. Rev. Chil. Cir., 55(2):204-8, 2003.

Manterola, C.; Pineda, V.; Vial, M. \& Losada, H. Is impact factor an appropriate index to determine the level of evidence of studies on therapeutic procedures in surgery journals? Cir. Esp., 78(2):96-9, 2005a.

Manterola, C.; Vial, M.; Pineda, V. \& Sanhueza, A. Systematic Review of Literature with Different Types of Designs. Int. J. Morphol., 27(4):1179-86, 2009.

Manterola, C.; Pineda, V.; Vial, M.; Losada, H. \& MINCIR Group. What is the methodologic quality of human therapy studies in ISI surgical publications? Ann. Surg., 244(5):827-32, 2006.

Manterola, C.; Pineda, V. \& Vial, M. Open versus laparoscopic resection in non-complicated colon cancer. A systematic review. Cir. Esp., 78(1):28-33, 2005b.

Mazzocchi, A.; Passi, L. \& Moretti, R. Retrospective analysis of 736 implants inserted without antibiotic therapy. J. Oral Maxillofac. Surg., 65(11):2321-3, 2007.

Moher, D.; Hopewell, S.; Schulz, K. F.; Montori, V.; Gøtzsche, P. C.; Devereaux, P. J.; Elbourne, D.; Egger, M.; Altman, D. G. \& CONSORT. CONSORT 2010 explanation and elaboration: updated guidelines for reporting parallel group randomised trials. Int. J. Surg., 10(1):28-55, 2012.

Morris, H. F.; Ochi, S.; Plezia, R.; Gilbert, H.; Dent, C. D.; Pikulski, J. \& Lambert, P. M. AICRG, Part III: The influence of antibiotic use on the survival of a new implant design. J. Oral Implantol., 30(3):144-51, 2004.

Nelson, S. \& Thomas, G. Bacterial persistence in dentoalveolar bone following extraction: a microbiological study and implications for dental implant treatment. Clin. Implant Dent. Relat. Res., 12(4):306-14, 2010.

Peterson, L. J. Antibiotic prophylaxis against wound infections in oral and maxillofacial surgery. J. Oral Maxillofac. Surg., 48(6):617-20, 1990.

Rasmusson, L.; Roos, J. \& Bystedt, H. A 10-year follow-up study of titanium dioxide-blasted implants. Clin. Implant Dent. Relat. Res., 7(1):36-42, 2005.

Resnik, R. R. \& Misch, C. Prophylactic antibiotic regimens in oral implantology: rationale and protocol. Implant Dent., 17(2):142-50, 2008.
Rizzo, S.; Zampetti, P.; Rodriguez, Y.; Baena, R.; Svanosio, D. \& Lupi, S. M. Retrospective analysis of 521 endosseous implants placed under antibiotic prophylaxis and review of literature. Minerva Stomatol., 59(3):75-88, 2010.

Sakka, S.; Baroudi, K. \& Nassani, M. Z. Factors associated with early and late failure of dental implants. J. Investig. Clin. Dent., 3(4):258-61, 2012.

Sharaf, B.; Jandali-Rifai, M.; Susarla, S. M. \& Dodson, T. B. Do perioperative antibiotics decrease implant failure? $\mathrm{J}$. Oral Maxillofac. Surg., 69(9):2345-50, 2011.

Sharaf, B. \& Dodson, T. B. Does the use of prophylactic antibiotics decrease implant failure? Oral Maxillofac. Surg. Clin. North Am., 23(4):547-50, 2011.

von Elm, E.; Altman, D. G.; Egger, M.; Pocock, S. J.; Gøtzsche, P. C.; Vandenbroucke, J. P. \& STROBE Initiative. Strengthening the Reporting of Observational Studies in Epidemiology (STROBE) statement: guidelines for reporting observational studies. BMJ, 335(7624):8068, 2007.

Wilson, W.; Taubert, K. A.; Gewitz, M.; Lockhart, P. B.; Baddour, L. M.; Levison, M.; Bolger, A.; Cabell, C. H.; Takahashi, M.; Baltimore, R. S.; Newburger, J. W.; Strom, B. L.; Tani, L. Y.; Gerber, M.; Bonow, R. O.; Pallasch, T.; Shulman, S. T.; Rowley, A. H.; Burns, J. C.; Ferrieri, P.; Gardner, T.; Goff, D. \& Durack, D. T. Prevention of infective endocarditis: Guidelines from the American Heart Association: A guideline from the American Heart Association Rheumatic Fever, Endocarditis and Kawasaki Disease Committee, Council on Cardiovascular Disease in the Young, and the Council on Clinical Cardiology, Council on Cardiovascular Surgery and Anesthesia, and the Quality of Care and Outcomes Research Interdisciplinary Working Group. J. Am. Dent. Assoc., 139 (Suppl. 1):3S-24S, 2008.

Correspondence to:

Claudia Asenjo Lobos MS, MSc

Victoria 232

Barrio Universitario

Concepción

CHILE

Email: casenjo@udec.cl

Received: 30-12-2014

Accepted: 09-03-2015 